\title{
The First Year Engineering Course at NC State University: Design and Implementation
}

\author{
Jerome P. Lavelle and Mary Clare Robbins \\ North Carolina State University
}

Introduction

Over the past three years the freshmen engineering course in the College of Engineering at North Carolina State University has been substantially redesigned. This paper describes the design, implementation and assessment of the new course. This course has undergone substantial change since 1996, Porter et al. previously reported on what had been implemented prior to $1999^{1}$. In the past three years, the Freshmen Engineering Program at NC State has continued to refine the course. The approach taken involves four steps: (1) define course learning objectives with constituents, (2) develop course content based on learning objectives (again with constituents), in the presence of constraints, (3) assess degree of achievement of learning objectives and effectiveness of content, and (4) utilize assessment data to implement changes which increase effectiveness and efficiency of resources.

\section{Design of the Course}

E 101: Introduction to the College of Engineering and Problem Solving is a required onesemester-hour course that is offered for all new entering engineering freshmen at NC State. There are approximately 1,150 such students each fall who are enrolled in this course. Over the past twenty years the course has been evolving — there has been substantial change over the last six years. The course is now focused on active team-based problem solving; understanding engineering as a discipline and career choice; effective team membership; understanding and using basic engineering design principles; effective oral and written communication; and understanding the resources, opportunities, and policies and rules that apply to engineering students at NC State. The stated Goals and Learning Outcomes of the course, as offered in the Fall 2002 semester, are given in Table 1.

The learning objectives of the course are achieved using an active/cooperative learning approach, targeted out-of-class activities, and special Engineering College events that focus on student involvement and accountability.

Implementation of the Course

Below are the important characteristics of the new E101 course:

- The course carries one-semester-hour credit and is required of all entering engineering freshmen students, students must pass the course to graduate;

- Students take the course for a grade (C-minimum must be earned);

- Classes meet once per week for a two-hour active learning lecture/lab session; 


\section{Table 1: Goals and Learning Objectives of the E101 Course, Fall 2002}

Goals and Objectives of the Course: This course is designed to introduce students to the field of Engineering and the study of Engineering as an academic discipline. The overall objective of the course is to integrate computer usage, teamwork, problem solving, and verbal/written language into a design project (within the course) and to thus develop the skills that are the foundation of a successful engineering career. An early understanding of these skills assists students throughout their undergraduate experience and beyond.

\section{E101 Course Learning Outcomes}

By the end of the semester, students will be able to:

1. Solve engineering problems by working in teams,

2. Understand specifics of the various engineering disciplines and about careers in engineering,

3. Apply a structured design process in solving engineering problems,

4. Demonstrate how and when to apply analytical methods to solve engineering problems,

5. Demonstrate knowledge of the resources and opportunities on campus that assist in achieving their unique educational and life goals,

6. Present engineering problems and solutions in both written and oral presentation modes.

- Class section sizes are limited to $\sim 40-48$ students — thus, in order to accommodate the $\sim 1,150$ incoming engineering students each fall, approximately $\sim 25-28$ sections of this course are offered;

- Classes meet in special computer equipped multi-media classrooms - this set-up facilitates the learning/teaching style desired and the classroom activities;

- Regular faculty from the 11 engineering departments in the College, as well as staff in the First Year Engineering Program serve as instructors of the course;

- There is no textbook for this course, all materials are available on the course web page and in the College of Engineering Student Handbook (students are required to purchase);

- Student Engineering Leaders (SELs) are used to assist in achieving the goals of the course, these are upper-level engineering students who serve as TAs for the various sections of the course (one SEL is designated as the Head SEL for coordination and training purposes, this person has previously been an SEL);

- There are 15 class meetings each semester (16 weeks minus fall break week), the subject of each of the class meetings, as well as the assignment/activity for the day, for the Fall 2002 semester are given in Table 2. From this table, one can see the various topics addressed in the Goals and Learning Objectives of the course. Under "Assignments/Activities" are listed both the assignments due, as well as any in-class activities for the day.

Below is a description of the main assignments, events and other course content items designed to implement the course learning objectives and assessment plan.

Goal-Setting Assignment: Students are asked to develop sets of one-week, one-semester and one-year goals. These sets include goals that are academic as well as professional in nature. This assignment is given early in the semester, at a time in the course when students are learning about the resources and opportunities in the College of Engineering at NC State. Examples of such resources/opportunities include: the seventeen undergraduate BS programs in the college, the cooperative education program, the study abroad program, student chapters of professional 
societies and other student groups, tutorial programs, career placement services, counseling center resources, university minors programs, dual-degree programs, university and college honors and scholars programs, undergraduate research opportunities, as well as others. The Goat Setting assignment challenges students to learn about what is on campus, and then think about their individual goals and what actions are necessary to achieve these goals. See Appendix 1.

Table 2: E101 Class Subjects, Fall 2002

\begin{tabular}{|c|c|c|}
\hline Week & Subject & Assignment/Activity \\
\hline 1 & $\begin{array}{l}\text { Course Overview; Introduction to the } \\
\text { College of Engineering }\end{array}$ & $\begin{array}{l}\text { In-Class: (1) HW \#1: Surveys (LASSI/LTM/PFEAS) } \\
\text { HW: (1) Goal-Setting Assignment }\end{array}$ \\
\hline 2 & $\begin{array}{l}\text { Success Strategies; Special guests: } \\
\text { Making College Count; University Career } \\
\text { Center }\end{array}$ & $\begin{array}{l}\text { In-Class: (1) Speaker presentations, ask questions } \\
\text { HW: (1) HW \#1 (Bring printout to class) } \\
\text { (2) Review HW \#2: Resume Assignment } \\
\text { (3) Journal Assignment \#1 due }\end{array}$ \\
\hline 3 & College of Engineering Welcome & 6:00-8:30 PM in Student Center, Required Attendance \\
\hline 4 & $\begin{array}{l}\text { Special guests: Engineering Librarians; } \\
\text { Library Research and Engineering } \\
\text { Analysis }\end{array}$ & $\begin{array}{l}\text { In-Class: (1) Speaker Presentations, ask questions } \\
\text { (2) Explain HW \#3: Straw Dome Design } \\
\text { (3) Biological \& Agricultural Engr. Presentation } \\
\text { HW: (1) Journal Assignment \#2 due }\end{array}$ \\
\hline 5 & $\begin{array}{l}\text { Managing Engineering Projects; } \\
\text { Effectiveness in Teamwork; Project } \\
\text { Management }\end{array}$ & $\begin{array}{l}\text { In-Class: (1) HW \#3: In-Class Work Time } \\
\text { (2) Chemical Engineering Presentation } \\
\text { HW: (1) HW \#2 due } \\
\text { (2) Journal Assignment \#3 due } \\
\end{array}$ \\
\hline 6 & $\begin{array}{l}\text { Design Projects \& Effective Problem } \\
\text { Solving; Video: Junkyard Wars }\end{array}$ & $\begin{array}{l}\text { In-Class: (1) Design Team Work Day } \\
\text { (2) Civil Engineering Presentation }\end{array}$ \\
\hline 7 & $\begin{array}{l}\text { Current Affairs \& Emerging Technologies; } \\
\text { Video: Engineering the Impossible }\end{array}$ & $\begin{array}{l}\text { In-Class: (1) Computer Science Presentation } \\
\text { HW (1) Due: HW \#3 due } \\
\text { (2) Design Project Team Contract due } \\
\text { (3) Journal Assignment \#4 due }\end{array}$ \\
\hline 8 & $\begin{array}{l}\text { Professional Development; Engineering } \\
\text { Ethics; Campus Resources; Spring } \\
\text { Semester Pre-Registration Information }\end{array}$ & $\begin{array}{l}\text { In-Class: (1) Electrical \& Computer Engr. Presentation } \\
\text { HW: (1) Design Project Scheduling Documents due } \\
\text { (2) Journal Assignment \#5 due }\end{array}$ \\
\hline 9 & No Class: Fall Break Week & No Class: Fall Break Week \\
\hline 10 & $\begin{array}{l}\text { Failure in Engineering Design, } \underline{\text { Video: }} \\
\text { World Trade Center: Anatomy of the } \\
\text { Collapse }\end{array}$ & $\begin{array}{l}\text { In-Class: (1) Industrial Engineering Presentation } \\
\text { HW: (1) Design Project, Preliminary Designs due } \\
\text { (2) Journal Assignment \#6 due }\end{array}$ \\
\hline 11 & Class Exam; Project Workday & $\begin{array}{l}\text { In-Class: (1) Materials Science \& Engr. Presentation } \\
\text { (2) Design Project Work Day }\end{array}$ \\
\hline 12 & Project Status Interim Report & $\begin{array}{l}\text { In-Class: (1) Mech. \& Aerospace Engr. Presentation } \\
\text { HW: (1) Design Project, Model/Prototype due } \\
\text { (2) Journal Assignment \#7 due }\end{array}$ \\
\hline 13 & $\begin{array}{l}\text { Project Evaluation by instructors; Design } \\
\text { Day Preparation }\end{array}$ & $\begin{array}{l}\text { In-Class: (1) Nuclear Engineering Presentation } \\
\text { HW: (1) Design Project Preliminary Results due } \\
\text { (2) Journal Assignment \#8 due }\end{array}$ \\
\hline 14 & $\begin{array}{l}\text { Looking to the Future; Lifelong Learning; } \\
\text { Design Day Preparation }\end{array}$ & $\begin{array}{l}\text { In-Class: (1) PFEAS } \\
\text { (2) Textile Engineering Presentation } \\
\text { HW: (1) Design Project Analysis of Results due } \\
\text { (2) Assessment of Project Design due }\end{array}$ \\
\hline 15 & Freshman Engineering Design Day & 9-12 noon \& 1-4 pm; McKimmon Conference Center \\
\hline 16 & $\begin{array}{l}\text { Design Project Oral } \\
\text { Presentation; Peer Review of } \\
\text { Design Teams; Wrap-up }\end{array}$ & $\begin{array}{l}\text { In-Class: (1) Final Design Project Oral Presentations } \\
\text { (2) Course Evaluations } \\
\text { HW: (1) Design Project Final Report due } \\
\text { (2) Journal Assignment \#9 due }\end{array}$ \\
\hline
\end{tabular}


Resume Assignment: In connection with the Goal-setting Assignment the objective of the Resume Assignment is to build on the process of "where am I, where do I want to be, and what do I have to do to get there?" Instructors in each section discuss the Resume Assignment and its connection to students' goals. Students attend a session conducted by the NC State Career Center entitled "What Makes a Good Resume." Many students use these resumes (even in their first year) to interview for summer internships, cooperative education work rotations, scholarships, and for other uses. See Appendix 2 for this assignment.

Making College Count: This one-hour seminar is coordinated through the University New Student Orientation office, a unit of the Division of Undergraduate Affairs. Making College Count is an entertaining, professionally done, and interactive college-success seminar designed to get students off to a good start. It provides key tips and advice on important issues related to academic, extracurricular, and career success. This session is scheduled early in the semester. A central theme throughout the course is to prepare students for the various "transitions" that they are experiencing as first-semester engineering students: academic, social, personal, and others. This event ties in well with that objective.

College of Engineering Welcome: The College of Engineering Welcome is an evening event that students attend that has two central components: (i) an opportunity/resource fair, and (ii) a keynote address by a local engineering leader. In addition, this event is developed to give each fall cohort a sense of connection to the College of Engineering, and to each other. The opportunity/resource fair consists of table displays and kiosks set up in a large ballroom facility in the University Student Center where students can browse and collect information from various offices and units on campus. In Fall 2002 there were 29 tables and over 40 representatives at the fair to discuss the opportunities/resources that they represent. Representatives from Cooperative Education, Study Abroad, and Women in Engineering also offered optional seminars in small meeting rooms for an interactive discussion with students on the special benefits of participation in these programs. Students also attend a keynote address from a local engineering leader. In the past two years the speakers were the CEO of howstuffworks.com and the female CEO/president of a highly successful local engineering consulting firm. The intent of this keynote address is to connect students with successful engineering leaders, to reinforce themes from the class in the message of the speaker, and to let the speaker talk about their own "lessons learned" and "secrets of success."

Departmental Presentations: All newly-admitted engineering student come into the College in an "unmatriculated" status. After successful completion of the "common first year" courses, students then matriculate (join) into the degree program of their choice (based on grades and space availability). In the E101 course, it is important that students come in contact with representatives from the various departments, as well as conduct independent individual research on the seventeen different degree programs. This exposure allows students to make an informed decision when it is time to matriculate. In addition, it gives them a sense of the breadth of engineering as a discipline. With the goal of exposing students to the various disciplines in mind, each week in class, student teams make 5-10 minute Departmental Presentations on each degree program in the College. These presentations use a standard format: department contact persons and location, degree programs offered, core courses, employment opportunities and other 
interesting information about the discipline. The presentations are done using MS-PowerPoint and are required to have the imported graphics from an MS-Excel spreadsheet data somewhere in the presentation.

Department Information Sessions: All students are required to attend two (2) department information sessions. Each academic department in the College develops and holds information sessions for the E101 student to attend. The objective of these sessions is to educate and excite students about the degree programs in the respective departments. Students choose the two sessions that they attend. The objective, again, is student exposure to the various disciplines.

Straw Dome Design Project: An important theme in the E101 course is introduction to, discussion of, and practice in, a standardized engineering design process. The semester-long design project covers several weeks, culminating at the end of the semester. To kick-off exposure to the design process, students are given a two-week "mini" design-project at the beginning of the semester. Students follow the same design steps and are evaluated by the same grading rubrics used in the larger semester-long project. Students design, analyze, build and report in this team-based project. See Appendix 3 for this assignment.

Examination: The examination is focused on information that students have been studying over the course of the semester, and which is available in the Engineering Student Handbook (created by the First Year Engineering Program staff). Students are responsible for knowing details related to the degree programs in the College, campus and College opportunities/resources, and University and College rules and regulations. The exam is administered through WebAssign (a campus computer tool used for giving exams on- line) and is given on a common exam night for all 1,150 students. A large bank of equivalent questions is used to develop a unique exam for each student when they log in.

Semester Design Project: The semester-long design project requires four-person student design teams to systematically step through the engineering design process. Students select one of several project choices offered through the course. Table 3 lists the major design process milestones: team contract, scheduling documents, preliminary design and prototype, preliminary results, analysis of results and assessment of design. The milestones ensure that all teams stay on task, and that they understand the importance, and connection, of all of the steps. The E101 Instructor Team (team made up all of the E101 instructors and other interested constituents) selects projects that have open design elements, so that various students' designs are possible (and inevitable). This allows the teams to explore and analyze various potential solutions. Projects that have been used in the past include: material transport, stiquito robotics, balsawood bridge, bottle rocket, and trebuchet. In addition, projects involving the nuclear reactor on campus, service-learning projects with a local middle school, and individual projects have been used. For several of the projects there is an end-of-semester project design competition (per the stated design requirements). These competitions, as well as displays of the projects and oral presentations, are part of the Freshmen Engineering Design Day event.

Freshmen Engineering Design Day: Freshmen Engineering Design Day is the culminating event for the design project assignment. This day-long event is held in a university conference facility. All $\sim 300$ teams are required to attend, display and present their work during this day. In the fall 
2002 semester, teams were divided into two shifts, 9:00am-12:00noon and 1:00-4:00pm. An invitation is sent to all of the students' parents to attend this event. In addition, local middle and high schools are invited, as well as the university community and local media. Student teams are given space on 4-by- 8 foot tables in the exhibition hall, and are asked to make and set up displays to exhibit the breadth of their project and the process they used to arrive at their final design. During a three-hour shift, the teams will be at their displays talking to visitors, participating in the design competitions, giving oral presentations, and talking to other teams about their projects.

Surveys and Journaling: Students complete three surveys as part of class assignments during the first week: Pittsburgh Freshman Engineering Attitudes Survey (PFEAS), Learning and Study Strategies Inventory (LASSI), and Learning Type Measure (LTM). Weekly Journal assignments are also accessed through the E 101 web site. These Journal Assignments capture students learning strategies as they progress through the semester. The surveys and journal work are part of the assessment system used in the class.

In Table 3 is give the grading scheme used for the E101 course. Notice the portion that each element of course content is assigned weight in the grade. This is done to encourage active participation and to guide students through the material in terms of importance and connection.

\section{Table 3: Grading for E101}

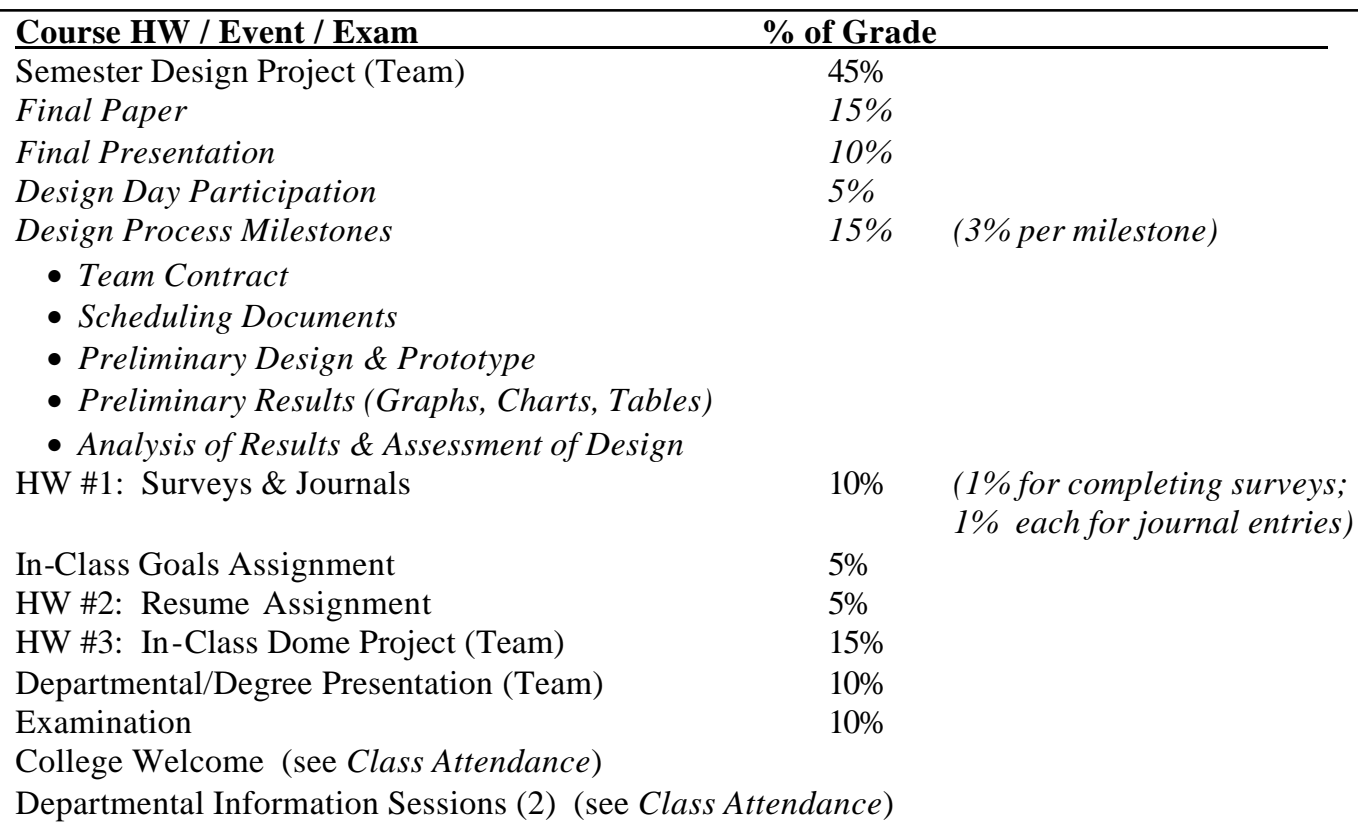

Class Attendance: Full participation in class is expected of all students. In accordance with NC State University policy, instructors in 100- and 200-level courses must keep a record of attendance throughout the semester. Attendance and promptness are expected. One absence and/or tardiness will be permitted. Each additional absence will result in a five-percentage point deduction from the final course grade. Each additional tardiness will result in a two-percentage point deduction from the final course grade. Attendance at Freshman Engineering Design Day and at the College Welcome is mandatory, and attendance at two Departmental Information Sessions is mandatory. 


\section{Assessment of the Course}

Planning and implementation without assessment offers no opportunity for data collection and improvement. The E101 course assessment plan includes the use of standardized surveys (LASSI/LTM/PFEAS), common grading rubrics, peer-to-peer evaluations, student journaling and course evaluations.

Table 4 provides a mapping of the stated learning objectives of the course to the course content and the assessment method used.

Table 4: E101 Mapping of Learning Objectives to Course Content and Assessment Method

\begin{tabular}{|c|c|c|}
\hline Learning Objective & Activity/Assignment/Event (Course Content) & Assessment Method \\
\hline $\begin{array}{l}\text { 1. Solve engineering problems by } \\
\text { working in teams, }\end{array}$ & $\begin{array}{l}\text { - Straw Dome Design Project } \\
\text { - Semester Design Project } \\
\text { - design phases } \\
\text { - team contract } \\
\text { - project scheduling }\end{array}$ & $\begin{array}{ll}\text { - } & \text { Team ratings rubric } \\
\text { - } & \text { Design Rubric } \\
\text { - } & \text { Course Evaluation }\end{array}$ \\
\hline $\begin{array}{l}\text { 2. Understand specifics of the } \\
\text { various engineering disciplines } \\
\text { and about careers in } \\
\text { engineering, }\end{array}$ & $\begin{array}{l}\text { - Departmental Presentations } \\
\text { - COE Welcome (information fair) } \\
\text { - Department Information Sessions }\end{array}$ & $\begin{array}{ll}\text { - } & \text { Team presentation } \\
\text { - } & \text { rubrics } \\
\text { - } & \text { Midterm } \\
& \text { examination } \\
\end{array}$ \\
\hline $\begin{array}{l}\text { 3. Apply a structured design } \\
\text { process in solving engineering } \\
\text { problems, }\end{array}$ & $\begin{array}{l}\text { - Straw Dome Design Project } \\
\text { - Semester Design Project } \\
\text { - all phases of design process }\end{array}$ & $\begin{array}{ll}- & \text { Design rubric } \\
\text { - } & \text { Course Evaluation } \\
\end{array}$ \\
\hline $\begin{array}{l}\text { 4. Demonstrate how and when to } \\
\text { apply analytical methods to } \\
\text { solve engineering problems, }\end{array}$ & $\begin{array}{l}\text { - Straw Dome Design Project } \\
\text { - Semester Design Project } \\
\text { - analysis of design results } \\
\text { - engineering failure }\end{array}$ & $\begin{array}{ll}- & \text { Design rubric } \\
\text { - } & \text { Course evaluation }\end{array}$ \\
\hline $\begin{array}{l}\text { 5. Demonstrate knowledge of the } \\
\text { resources and opportunities on } \\
\text { campus that assist in achieving } \\
\text { their unique educational and life } \\
\text { goals, }\end{array}$ & $\begin{array}{l}\text { - } \text { Goals Assignment } \\
\text { - Resume Assignment } \\
\text { - Departmental Presentations } \\
\text { - COE Welcome (information fair) } \\
\text { - Department Information Sessions }\end{array}$ & $\begin{array}{ll}\text { - } & \text { Examination } \\
\text { - } & \text { Dourse evaluation } \\
& \text { pepartmental } \\
& \text { presentation rubric }\end{array}$ \\
\hline $\begin{array}{l}\text { 6. Present engineering problems } \\
\text { and solutions in both written } \\
\text { and oral presentation modes. }\end{array}$ & $\begin{array}{l}\text { - } \text { Straw Dome Design Project } \\
\text { - } \text { Freshmen Engineering Design Day } \\
\text { - Semester Design Project } \\
\text { - final written report } \\
\text { - final oral presentation } \\
\text { - } \text { Resume Assignment } \\
\text { - Goals Assignment }\end{array}$ & $\begin{array}{l}\text { - } \text { Design rubric } \\
\text { - Oral presentation } \\
\text { rubric } \\
\text { - Course evaluation }\end{array}$ \\
\hline
\end{tabular}

Grading Rubrics: An important component of the assessment approach has been the use of grading rubrics. The rubrics have been developed to provide clear expectations for the students. The content and breadth of the expectation is explicit. Students have responded very positively to the use of these rubrics; most students are very familiar with grading rubrics and their uses. For the E101 instructors and SELs the grading rubrics provide a common and consistent mechanism 
to evaluate student work and assign grades in light of the learning objectives. Instructors and SELs are given a workshop at the beginning of the semester to "calibrate" their use of the rubrics.

Connection to ABET: The E101 course has been developed to address the needs of firstsemester engineering students as well as the degree-granting engineering programs at NC State University. There is a clear connection between the E101 learning objectives (and list of course content materials) and many of the program objectives prescribed by ABET. Work in a team environment, engineering ethics, engineering design, written and oral communication are all themes contained in ABET's Criterion 3. First-semester engineering students' ABET requirements in these areas are not finished with E101. Rather, exposure in these areas is the beginning point for the departments' treatment in these domains. The important Criterion 3 E101 content is "connected to" additional departmental experiences. Assessment at the freshmen level is important for departments because of the longitudinal "value added" that can be demonstrated over students' undergraduate experience. Thus, the E101 assessment is not only important to improve the course, it is also very important from a department ABET-process perspective.

For details concerning the assessment of the E101 course, including copies of the grading rubrics, please see the companion paper also in these 2003 ASEE Conference Proceedings entitled Assessment of Introduction to Engineering and Problem-Solving Course, by Spurlin, Lavelle, Robbins, and Rajala ${ }^{2}$.

\section{Conclusion}

The E101 course at NC State University provides entering engineering students with an important first-semester experience. The course has been designed to address several learning objectives important for student success. The approach taken in designing (re-designing) the course involves four steps: (1) define course learning objectives, (2) develop course content based on learning objectives, in the presence of constraints, (3) assess degree of achievement of learning objectives and effectiveness of content, and (4) utilize assessment data to implement changes which increase effectiveness and efficiency of resources. This paper has given an overview of the substantive changes that have been made to the course over the past three years. The major components of steps (1)-(4) have been described.

\section{Bibliography}

1 Porter, R. L., Bottomley, L. J., Robbins, M. C., and Yarbrough, W. V , "Introduction to Engineering Problem Solving - A New Course for 1,100 1 ${ }^{\text {st }}$-Year Engineering Students," 1999 ASEE Annual Conference Proceedings, Charlotte, NC, June 20 - 23, 1999.

2 Spurlin, J.E., Lavelle, J.P., Robbins, M.C., and Rajala, S.A., “Assessment of Introduction to Engineering and Problem-Solving Course," 2003 Annual Conference Proceedings, Nashville, TN, June 20-23, 2003. 


\section{Author Biographical Information}

JEROME P. LAVELLE, Ph.D.

Dr. Lavelle is Assistant Dean in the College of Engineering, and Associate Professor in Industrial Engineering, at North Carolina State University in Raleigh, NC. Dr. Lavelle is past chair of ASEE's engineering economy and engineering management divisions. His areas of research and teaching include engineering economics and engineering management, project management, and engineering education.

MARY CLARE ROBBINS, Ph.D.

Dr. Robbins is Coordinator of Advising in the First Year Engineering Program in the College of Engineering at North Carolina State University. Dr. Robbins received her PhD from North Carolina State University

Appendices

$\underline{\text { Appendix 1: Goal-Setting Assignment }}$

Consider your Personal, Academic, and Career Goals

1. List your Personal goals for the coming week. Make sure they are realistic, specific, action-based, measurable, and time-based!

2. List your Academic / Educational goals for the coming week. Again, make sure they are realistic, specific, action-based, measurable, and time-based!

3. Now that you have thought about your goals for the coming week, list your shortterm (semester long) Personal and Academic / Educational goals. Again, keep them realistic, specific, action-based, measurable, and time-based!

4. Submit your goals through Wolfware.

\section{Appendix 2: Resume Assignment}

1. Create / revise your personal resume.

- Submit it electronically via Wolfware.

- Submit a hard copy in class.

(Consider referencing http://ncsu.placementmanual.com/ for very useful information about building resumes.)

2. Optional: Visit the University Career Center.

3. Optional: Visit the University Career Center online at http://www.ncsu.edu/career

Other Optional activities that may be of interest:

4. Using the Explore Careers link on the University Career Center homepage become aware of the various career assessment tools and on-line career instruments available as you are deciding among various career fields. Specifically review the resources found under Career Links -- Engineering.

5. Using the Exploring Careers link review the information under What Can I do with a Major in...

6. Review the information regarding Career Fairs, Workshops, Job Listings \& Links, and other OnCampus Interviewing opportunities. 


\section{Appendix 3: Straw Dome Paper}

Objectives: To provide first-hand experience in applying the engineering design process, to gain experience in teamwork, and to create a written report of the process.

Assigned: $\quad$ Week \#4: Sept. 9 - 13, 2002

Paper Due: Week \#7: Sept. 30 - Oct. 4, 2002

In Class Activities (Week \#4):

1. Elements of the design process will be presented and discussed.

2.Engineering services librarians will explain how to:

Research sources.

Summarize research findings.

Document references.

\section{Problem:}

Design and build a dome (a curved three-dimensional rigid structure). It must be freestanding and retain its structural integrity while supporting its own weight. Your design should maximize the enclosed volume. You must be able to determine the volume of the enclosure during the development and construction phase of the process (in class, Week \#5). In addition, the design should be such that the diameter of an intact 12-oz. soft drink (aluminum can) container cannot be passed through any gaps in the structure.

\section{Materials (provided):}

5 feet of masking tape

50 straws (encased in paper)

Prior to Week \#5 Class

The following aspects of the design process should be completed with your team prior to class:

1. Problem identification \& working criteria

2. Research sources

3. Summarize research findings

4. Project Management

Develop your team contract. Include:

- Team name, list members with contact information, and each member's role in project

- Team mission statement

What is our team all about?

- Anticipated results (team goals)

What do we hope to accomplish?

- Ground rules/guiding principles for team participation with consequences 
Attendance, promptness, participation, interruptions, basic conversational courtesies, confidentiality, assignments, breaks, rotation of responsibilities, meeting place and time/notification procedures

Project Schedule

- List of specific tasks that will need to be completed for your project

- Schedule for completion of these tasks

- Who will be responsible for what task?

- How closely did you actually follow your schedule \& distribution of tasks?

Resources

- Materials

- Tools (Decide what, if any, tools you may want to bring to class for the construction phase of the project)

- Other resources

- Mock budget

5. Identification of feasible alternatives

Design Drawings

6. Analytical method (determination of volume)

7. Selection \& analysis of alternatives

BRING TO CLASS (Week \#5) TO HAND IN:

1) sketch of your design;

2) method/formula that you will use for calculating volume;

3) list of references; and

4) list of team meetings (dates \& times) held to complete this assignment.

In class activities (week \#5):

Develop \& build project

Test project

Analyze \& present results

Paper (due week \#7):

Prepare a written team report of this project using the format given in the attached grading rubric. The paper must be written using Microsoft Word. Please include a separate title page. 